\title{
Legal Rulings on Medical Issues: A Comparative Study between the Malaysian and Islamic Law
}

Puteri Nemie Jahn Kassim

Civil Law Department, Ahmad Ibrahim Kulliyyah of Laws, International Islamic University Malaysia, Kuala Lumpur.

\section{ABSTRACT}

The medical profession is amongst the professions that offer tremendous benefit to the entire humanity. Nevertheless, the responsibilities that they have to undertake in their daily practice are constantly increasing as they deal with two most precious commodities of mankind, which is life and health. The demands for accountability when 'the consequences of an action are considered not to be at par with the expectations' has become a common trend within the society recently. Law, being an instrument of social regulation, intervenes to establish the rights and responsibilities in medical practice to determine the boundaries of rightful conducts in areas where there exist conflicts of moral, ethical and religious issues. Therefore, it is pertinent for Muslim doctors to keep abreast with the developing law that is governing their practices and at the same time, to ensure that any deliberations flourish within the confines of Islamic law. By employing qualitative research method, namely, doctrinal analysis, this paper seeks to discuss the legal rulings from the Malaysian and Islamic law perspectives relating to significant and current medical issues such as negligence, confidentiality, assisted reproductive technologies, abortion, euthanasia, organ transplantation and sterilisation.

KEYWORDS: Comparative, Islamic Law, Legal Rulings, Malaysian Law, Medical

\section{INTRODUCTION}

The medical profession is amongst the professions that offer tremendous benefit to mankind. In Surah al-Maidah, Allah S.W.T. clearly praised such a duty by stating to the effect: "And if any one saved a life, it would be as if he saved the life of the whole mankind". ${ }^{1}$ In the same verse, Allah s.w.t. had also reiterated by stating to the effect: "And if anyone kill a life....it would be as if he had killed the whole mankind." Thus, it can be seen that this noble profession shoulders heavy responsibilities in executing their daily practice. They must not only be fully responsible and accountable for their actions, ${ }^{i}$ but more importantly, they must be cautious in performing their duties so that they do not inflict harm and thus, protect the rights of affected parties. ${ }^{i i}$ The advent in medicine, science and technology has also created a host of problems involving ethical, legal and religious issues. Muslim doctors should not just be knowledgeable in their area of expertise but they also need to keep abreast with the legal rulings affecting their medical practice, which relates to contemporary issues on negligence, confidentiality, assisted reproductive technologies, abortion, euthanasia, organ transplantation and sterilisation. Having the legal knowledge in these areas will enable them to draw the boundaries of rightful conduct which has been determined by the Malaysian and Islamic law.

Puteri Nemie Jahn Kassim

Civil Law Department,

Ahmad Ibrahim Kulliyyah of Laws,

International Islamic University Malaysia,

PO Box 10, 50728, Kuala Lumpur.

Email: nemie@iium.edu.my

\section{MEDICAL NEGLIGENCE}

The development of Malaysian medical law has largely relied on principles of English common law. This practice is attributable to the fact that Malaysia inherits much of its legal system from the common law in England, having been under British colonial rule in the $19^{\text {th }}$ and $20^{\text {th }}$ centuries. The prevailing influence of the laws of England is codified in section 3 of the Malaysian Civil Law Act 1956. ${ }^{i i i}$ Medical negligence is concerned with the tort of negligence applied in the specific context of the provision of healthcare. In Loghelly Iron \& Coal $\checkmark$ M'Mullan, Lord Wright stated that "negligence means more than heedless or careless conduct...it properly connotes the complex concept of duty, breach and damage thereby suffered by the person to whom the duty was owing"iv. Thus, it can be seen that to establish negligence, it has to be proven that there is (a) a duty of care or an existing legal duty on the part of the doctor to the patient; (b) a breach of duty or failure to conform to the standard of care which the doctor owes to the patient; (c) causation or consequential damage to the patient, that is, the patient suffers damage as a result of the doctor's breach of duty. Subsequently, doctors are expected to adhere to a certain standard as demanded by the profession. The standard of care demanded by law for doctors is the standard of care observed by a reasonably competent member of the profession. A doctor will not be considered negligent if he has acted according to a practice accepted as proper by a body of medical men who possess similar skills to the doctor in question. ${ }^{v}$ However, the standard of care for doctors is no longer a matter of medical judgment but a matter of law as the court will determine which medical 
opinion reaches up to a logical analysis. ${ }^{3}$ Accordingly, "the standard of care applicable is not determined solely or primarily by reference to the practice followed or supported by a responsible body of opinion in the medical profession. Thus, while evidence of acceptable medical practice is a useful guide, it is ultimately for the court to adjudicate on what is the appropriate standard of care, drawing upon the totality of the evidence presented."vi

Similarly, in Islam, doctors are expected to be a person who has the required skills and knowledge to treat the sick. Islam expects the highest standard of care to be given by any profession including the medical profession. The general rule is that a doctor or any medical professional must exercise care according to the standards of reasonable competent medical men of his age. ${ }^{4}$ If a person who is without the required knowledge and qualification treats another, he may become liable under the principle of strict liability (mas'uliyyah mutlaqah). Under this principle, compensation can be given to the patient without him having to prove any wrongdoing on the person who offers the treatment. This principle of strict liability under Islamic law is based on the hadith: "Whosoever treats people without knowledge of medicine before that becomes liable." ${ }^{5}$ Classical Muslim scholars have supported the sentiments embodied in the above Shari'ah textual injunctions. Imam Shafi'i, the founder of the Shafi'i's school of legal thought, states that: "A doctor is liable to pay compensation if he is negligent. ${ }^{6}$ Imam Al-Nawawi, a Shafi" $i$ scholar, states to the effect "a surgeon who bleeds a patient or apply leeches to him does not incur any responsibility, even though the sick man succumbs, provided that the operator does not overstep the limits imposed by science in operations of that nature." Ibn Qudamah discussed the law of talion in medical negligence cases: "a surgeon who, on proper authorisation, bleeds any one or apply leeches to him, is in no way responsible for the consequences; and an executioner who carries out a sentence of death or of flogging upon the authorisation of the Sovereign is merely the latter's instrument, unless he knows that the order is from a tyrant, or given in error. In these two cases he would himself be liable under the law of talion, unless acting under violent compulsion." 8 The opinions of other doctors specialising in the same field ( $R a^{\prime} \mathrm{yu}$ al-Khabir) is also important to determine doctor's liability. In Surah al-Nahl, Allah (SWT) says to the effect: "and before you were messengers we sent who are men to whom we granted inspiration, if you realise this, ask of those who possess the message." Thus, opinions of doctors are given strong weight in determining doctor's liability. In proving medical negligence under Islamic Law, the following conditions are considered necessary to establish liability: (i) al-Ta'addi (Breach of duty)-In order to be liable for his conduct, the doctor must have committed a breach of duty (ta'addi). Under the doctrine of ta'addi, Islamic law recognises two types of breach, namely a direct breach (ta'addi ijabi) and indirect breach (ta'addi salbi). ${ }^{9}$ A direct breach includes any act that directly violates the code of conduct for doctors that have been drawn up for that particular country. ${ }^{10}$ However, the doctrine of ta'addi will not be applicable to acts, which are consented to by the patients. The doctrine is also not applicable to acts done by doctors in order to save life; (ii) al-Darar (Damage/ Injury)-The second condition that must be satisfied is that the wrongful act must cause injury to the patient, whether physical injury (darar hissi) or moral injury (darar ma'nawi). ${ }^{11}$ Dharar hissi includes any injury inflicted to the patient's body; (iii) alIfdha' (Relationship) - This condition requires the existence of a relationship between the first and the second condition stated above. In other words, the breach of duty by the doctor must have caused the injury alleged. ${ }^{12}$ In other words, there has to be a causal connection between the acts of the doctors and the damage done. If both doctors contributed to the injury concerned, then both will be liable. If it is established that only one doctor caused the injury concerned, then the other will escape liability. ${ }^{13}$ There are two types of al-Ifdhai'. Firstly, alMubasharah (direct relationship) which includes the existence of a direct relationship between the breach of duty and the damage done. ${ }^{14}$ Secondly, alTasabbub (indirect relationship), which includes the existence of indirect relationship between the breach of duty and the damage done. ${ }^{15}$ In other words, if the doctor's breach of duty indirectly causes the injury in question, the doctor will be liable if there is a connection between the act and the injury. ${ }^{16}$

\section{MEDICAL CONFIDENTIALITY}

The duty of medical confidentiality has been one of the core duties of medical practice as information created, disclosed, acquired directly or indirectly during the doctor-patient relationship is considered confidential and requires legitimate protection. Further, preserving confidentiality on the premise that the relationship between doctor and patient has been built on trust and confidence renders the duty to be seen as sacrosanct. ${ }^{17}$ The source for this duty can be found not only in the Hippocratic Oath, codes of ethics, religious tenets but also in the common law, principles of equity and statutory provisions. However, although the basis of the law's protection of confidence is that there is a public interest that confidences should be preserved and protected by law, nevertheless that public interest may be outweighed by some other countervailing public interest which favours disclosure. ${ }^{18}$ The Malaysian Medical Council Revised Guidelines 2011 on Confidentiality states that a medical practitioner may "disclose personal information if (a) it is required by law (b) the patient consent either implicitly for the sake of their own care or expressly for other purposes; or (c) it is justified in the public interest" (at provision 3). Therefore, the duty of confidentiality is not absolute and the law recognises several exceptions for breaching the duty 
of confidentiality. A number of statutory provisions provide for the disclosure of information by medical practitioners. There are several legislations in Malaysia that requires medical practitioners to disclose patient information to the relevant authorities, for example, the Prevention and Control of Infectious Diseases Act 1988 (Act 342), the Poisons Act 1952 (Act 366) (sections 21(2), 23(2) and 24; Regulations 19 and 20 of the Poisons (Psychotropic Substances) Regulations 1989) and the Criminal Procedure Code (FMS Chapter 6). For instance, section 10(2) of the Prevention and Control of Infectious Diseases Act 1988 requires medical practitioners to provide information of infectious diseases to the nearest Medical Officer of Health in the prescribed form. Similarly, section 27 of the Child Act 2001 states that "if a medical officer ...believes on reasonable grounds that a child he is examining or treating is physically or emotionally injured as a result of being ill-treated, neglected, abandoned or exposed, or is sexually abused, he shall immediately inform the Protector" (subsection 1) and failing to comply with this, the medical officer "commits an offence and shall on conviction be liable to a fine not exceeding two years or to both" (subsection 2). Disclosure may also be justified on the basis of the need to protect those at risk of death or serious harm as was considered in W v Egdell [1990] 1 All ER 835, which depicts that, in exceptional circumstances, the duty of confidentiality could be breached. However, for disclosure to be lawful, there must be an overwhelming public interest in disclosure. A real and serious risk of danger to the public must be shown before the public interest exception is made out and the public interest exception can only justify disclosure so long as the threat persists. ${ }^{19}$

Similarly, Islam holds the right of privacy of human beings in high esteem and this right is given paramount and important consideration under the Shari'ah. There are numerous Qur'anic verses and Hadiths explaining the significance of privacy in Islam. In Surah an-Nur, (verse 27), the Quranic verse stresses physical privacy: "O you who believe! Enter not houses other than your own, until you have asked permission and saluted those in them, that is the best for you, in order that you may heed (what is seemly)." Further in Surah al-Hujurat verse 12, Allah s.w.t. stated to the effect "O you who believe! Avoid suspicion as much as possible, for suspicion in some cases is a sin. And spy not on each other, nor speak ill of each other behind their backs." The rule to respect one's privacy is not an obligation imposed on adults only but applies to children as well. vii Thus, Muslims are strictly advised not to indulge in activities that will bring another Muslim's name, reputation and business in contempt. The Prophet Muhammad (P.B.U.H) has also stated that "the believer is not one who defames, slanders, nor is obscene." ${ }^{20}$ Guided by the respected principle of privacy in Islam, medical professionals are forbidden to disclose information they obtain from their patient to others. Article 29 of the Islamic Charter of Health Ethics ${ }^{\text {viii }}$ provides that: "A physician may not disclose a personal secret that has come to his knowledge through the performance of his profession, whether the patient confides the secret to him, or the physician comes to know it in the course of his work..." However, the physician is allowed to disclose information about his patient according to the following exceptions: (i) If disclosure of a person's secret is done at his own request, which should be in writing or if disclosure of a secret is in the interest of the patient or society; (ii) if the laws in operation require disclosure of the secret, or an order to disclose it is made by a judicial authority; (iii) if the purpose of disclosing the secret is to prevent crime, in which case the disclosure should be strictly to the official authority concerned and to no other party; (iv) if the disclosure of a person's secret is in the interest of the patient's spouse, provided that it is made to the couple, and not to one without the other; $(v)$ if the physician makes the disclosure in defending himself before a judicial authority at its request and in as much as the defence requires and (vi) if the purpose of disclosing the secret is to prevent the spread of an infectious disease that would be harmful to society members provided that the disclosure is made only to the concerned health authorities. ${ }^{\mathrm{ix}}$

\section{ASSISTED REPRODUCTIVE TECHNOLOGIES}

Advanced medical processes have introduced many modern reproductive techniques which allow conception to occur without resorting to normal sexual intercourse. These artificial reproductive methods have helped many couples having difficulty conceiving children naturally. ${ }^{22}$ The resulting childbirth may give enormous happiness to the childless couple but the legal and ethical implications of such processes are many, particularly, if an unidentified donor sperm is used or another woman (surrogate mother) is used to carry the child other than the party to the marriage. The Ministry of Health of Malaysia has drafted the Assisted Reproductive Technologies (ART) Bill and it is hoped that this will have a specific legislation governing this matter very soon. However, it is clear that ART using donor sperms and surrogacy contracts will not be lawful in Malaysia. This is because the principles in Shari'ah and public policy considerations have been influential in drafting of the relevant provisions in the future legislation. ${ }^{23}$ In Islam, individual rights must be balanced with the right of others and the duties imposed by the religion. Marriage is a religious duty as well as a social necessity in Islam. This is because it allows one to abstain from many illegitimate conducts and learn to shoulder responsibilities. In the Holy Qur'an, Allah S.W.T. Surah al-Rum, ${ }^{24}$ states to the effect: "Among His signs is that He created mates for you from among yourselves, so that you may find tranquility with them, and He has put love and compassion between you. Verily in this are signs for people who reflect". Prophet Muhammad (P.B.U.H) has emphasized on the importance of marriage by saying, "Marriage is my tradition. He who rejects my 
tradition is not of me." In fact, he described marriage as half of the religion, and the other half being God-consciousness." 25

Procreation of children is considered to be one of the important aspects of marriage. Thus, it is a legitimate for childless couples to seek all kinds of procedure to enable them to have children as to enhance the psychological and social happiness of their married life. ${ }^{26}$ This is clearly stated in the Holy Qur'an in which Allah (S.W.T) has stated to the effect that: "Wealth and children are the ornament of this life on earth."27 Various types of assisted reproductive technologies will be lawful if it only involves a married couple while the marriage is valid and sufficient and meticulous care is taken to avoid any confusion of lineage. ${ }^{x}$ Therefore, if the semen belongs to a husband and the ovum is produced by his own wife and does not involve any donors as well as third party for gestation, then the technique will be allowed. Artificial insemination by husband $(\mathrm{AlH})$ would be lawful during the subsistence of the marriage whereas artificial insemination by a donor would not be lawful as it does not guard the purity of lineage. The involvement of a third person in the equation is totally unacceptable whether in the form of a sperm, an ovum, an embryo or a uterus. ${ }^{28}$ Hence, the widespread practice in ART facilities of sperm, ovum and embryo donation and the "rental" of uterus is incompatible with the Islamic injunctions related to human reproduction. Thus, surrogacy in all its forms is not allowed in Islam. Further, once the marital contract has been terminated either due to divorce or death of the husband, assisted reproduction cannot be performed on the ex-wife or widow using sperm cells from the former or dead husband $\mathrm{d}^{\mathrm{xi}}$ or using the previously preserved embryos

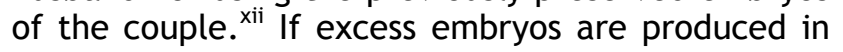
ART programs, it can be preserved and stored after the procuring informed consent of the couple is obtained and the embryos continue to remain the property of the couple. It can only be transferred to the uterus of the wife and only during the validity of the marriage contract. ${ }^{29}$ This is to ensure the protection of the five essential values in a man's life primarily in this case, his faith and progeny. Preservation of embryos should only be allowed in specially designated sperm and embryo banks or ART centres accredited by the relevant health authorities. An accurate and full proof system of documentation must be in place to guard against mixing of lineages and commercialism. Confidentiality of information should not be breached and tight security procedures should prevent unauthorized access to records. ${ }^{30}$

\section{ABORTION}

Abortion means the termination of a pregnancy before the fetus is viable or able to survive outside the uterus. The Oxford Dictionary of Law defined abortion as the termination of a pregnancy or premature expulsion of a fetus from the womb before the normal period of gestation is complete. ${ }^{31}$
Generally, abortion is unlawful in Malaysia and the relevant provisions under the Malaysian law are dealt with under sections 312 to 316 of the Penal Code (Revised 1997) Act (Act 574). Section 312 provides that "whoever voluntarily causes a woman with child to miscarry shall be punished with imprisonment for a term which may extend to three years, or with fine, or with both; and if the woman is quick with child, shall be punished with imprisonment for a term which may extend to seven years, and shall also be liable to fine." If the woman dies as a result of the abortion then the punishment will be much more severe as stated in section 314 . However, an exception stated under section 312 which can also be read together with section 314 allows abortion to be conducted by "a medical practitioner registered under the Medical Act 1971 [Act 50] who terminates the pregnancy of a woman if such medical practitioner is of the opinion, formed in good faith, that the continuance of the pregnancy would involve risk to the life of the pregnant woman, or injury to the mental or physical health or the pregnant woman, greater than if the pregnancy were terminated." Therefore, abortion will not be an offence under the above exception is satisfied. In Public Prosecutor $v$ Dr Nadason Kanalingam $^{\text {xiii }}$, an obstetrician and gynaecologist was charged under section 312 of the Penal Code for voluntarily causing a woman with child to miscarry and such miscarriage was not done in good faith for the purpose of saving her life. Although the defendant had conducted a tubal ligation on the woman, she was still found to be about fourteen weeks pregnant. As she had enlarged varicose veins, the defendant injected her with 150 c.c. saline. She was in labour within 48 hours and a male fetus was aborted. The defendant claimed that he performed the operation in good faith for the purpose of saving the life of the woman who was suffering from enlarged varicose veins which might lead to pulmonary embolism. However, from the evidence adduced in court, the judge held that the abortion was not done in good faith for the purpose of saving the mother's life as the defendant "had not given reasonable thought and not taken enough steps to examine the woman further."xiv The defendant's "finding that the woman had enlarged or bad varicose veins are no other than the result of his mere clinical examination." $\times v$ The defendant was sentenced to a fine of RM3500, in default four months' imprisonment.

Islam regards life, including that of a fetus, as sacred. There are no direct verses in the Holy Qur'an that prohibit termination of pregnancy or abortion but there are many verses that prohibit taking away life without legitimate reasons. For example, in Surah al-Isra', Allah S.W.T. states to the effect that "Kill not your children for fear of want (poverty), as it is we who shall provide sustenance for them as well as for you. Verily killing them is a great sin." 32 The majority of Muslim scholars assert that abortion after the introduction of the soul, or 120 days after conception, is forbidden. This is based on a Hadith attributed to 
the Prophet (P.B.U.H), in which the Prophet (P.B.U.H). stated, "The creation of one of you as a sperm in the belly of his mother takes forty days, then for a similar period he is a clot of blood, and then again for an equal period, he is a morsel. Then God sends an angel who breathes spirit into him." 33 However, there are differences in opinion amongst jurists on whether abortion can take place during the first 120 days. The most liberal position is by the Hanafi jurists who argue that since the fetus does not have a soul it is not considered alive. Abortion can be procured at this stage with the permission from both the husband and wife. The majority of Maliki jurists take a stricter view in that abortion is not allowed even before the period of forty days. ${ }^{x v i}$ The Hanbali and Shafii jurists, on the other hand, argue it is legally permissible only within the first 40 days since implantation of the zygote into the mother's uterus has not occurred up to that point. Once implantation occurs, they argue, although the fetus is not considered alive it is still "a part" of the mother. The majority position of the jurists opined that abortion is forbidden after 120 days, unless it is to save the life of the mother. As a result of diversity of legal opinions, various Islamic institutions have taken different positions on the issue. For instance, the Islamic Research Academy affiliated with Al-Azhar University in Cairo, Egypt has recently stated that abortion is illegal at all times and any Muslim woman committing abortion is guilty of a crime. In contrast, the Islamic World League of Saudi Arabia have issued a fatwa stating abortion is legal if the fetus is grossly malformed or has an untreatable chronic disease and if the abortion is performed before 120 days. The Legal Opinion (Fatwa) Authority at the Kuwaiti Ministry of Endowments (Waqfs) considers that if continued pregnancy poses a threat to the mother, preservation of her life should take priority, because she is the pillar for the family and has many obligations to fulfill compared to the fetus. Finally, in cases of rape, Dr. Yusuf Qardawi, although he generally takes the position that abortion is forbidden at all times, issued a fatwa granting rape victims the right to an abortion before 120 days. ${ }^{34}$

\section{EUTHANASIA}

The ethical principle of sanctity of life has always demanded that life is sacred and should be respected. However, there are many occasions, in which a doctor may face dilemmas particularly, in handling terminally ill patients. ${ }^{35}$ In such instances, patients may demand that their lives be terminated to reduce their suffering or family members may request for their loved ones to be allowed to die with decency and dignity. ${ }^{\text {xvii }}$ In dealing with such instances, the Malaysian ethical codes and law has yet to develop to the fullest extent. English cases are being referred where guidance cannot be found under the Malaysian statutory enactments and judicial cases. The Malaysian Penal Code further makes it clear that a doctor who deliberately takes active steps to cause death or hasten death of his terminally ill patient would be committing murder under section 300 of the Penal Code (Amendment) Act 1989 [Act 727] $^{\text {xviii }}$, if it had been performed against the wishes of his patient. However, even if the patient consents, the doctor may be committing the offence of culpable homicide under section 299 of the Penal Code (Amendment) Act 1989 [Act 727] as it is a direct violation of the principle of sanctity of life. ${ }^{\text {ix }}$ Active measures to cut short the life of a terminally ill patient are forbidden. As long as there is an intention to kill, it is sufficient to make it an unlawful act. $^{36}$ The reason behind the intention makes no difference and the request by patient would be irrelevant. ${ }^{x x}$

However, withdrawal or withholding treatment including withdrawal of nutrition and hydration may be held lawful in certain circumstances, particularly, where recovery was unlikely, continuance of treatment would be futile and not in patient's best interests. ${ }^{37}$ Such requirements are discussed at length in the case of Airedale NHS Trust $v$ Bland ${ }^{\mathrm{x} \times \mathrm{i}}$ and the decisions would offer a good precedent by allowing withholding and withdrawing treatment when the patient's condition is futile. In determining futility, the courts will look at factors such as whether there was any realistic prospect of the patient recovering, are there new avenues of treatment that might lead him regaining consciousness, is there any clinical benefit to the patient for the continuation of treatment and is it in his best interests to allow him to die naturally. The current practice by the Malaysian doctors is similar to the decision of Airedale in which withholding and withdrawal of treatment is considered lawful where continued treatment is not in the best interests of the patient. The difference between Airedale and the current practice in Malaysia is that after nutrition and hydration is withdrawn from the patient in the hospital, the patient would be brought home and nutrition and hydration would continue to be provided by the patient's relatives until the patient dies. ${ }^{38}$

Islam safeguards the sanctity of human life and regards life as a gift from God. In Surah al-Hajj, Allah S.W.T. states to the effect: "It is He who has given you life, then $\mathrm{He}$ will cause you to die, and then will bring you back to life. Man is indeed ungrateful."xxii Thus, since it is Allah S.W.T. that bestows life, it is He who only has the right to take it away. No one has the right to terminate a life, except when applying one of Allah swt's prescribed punishments. There are also many verses in the Holy Qur'an which forbids a person to kill another without proper justification. In Surah al-Nisa', Allah S.W.T. states to the effect: "Whoever kills a believer intentionally will be punished in hellfire where he will stay for eternity. He will incur the wrath of God, who will curse him and have a terrible penalty in store for him." ${ }^{39}$ The Prophet Muhammad's (P.B.U.H), traditions also confirm that killing a human being is one of the worst cardinal sins. The Prophet, (P.B.U.H), has been quoted as saying: "The most serious of cardinal sins are ascribing a partner to God, killing a human being, 
being undutiful to one's parents, and making a false statement, ${ }^{x \text { xiii }}$ and in another version "and giving a false testimony" is added. ${ }^{\text {xiv }}$ The Qur'an is also clear in prohibiting a person from committing suicide. In Surah al-Nisa', Allah S.W.T. states to the effect: "Do not kill yourselves as God has been to you very merciful" 40 . These sources from the Qur'an and hadith illustrate the sanctity of human life, prohibition of killing a human being with no justification, and prohibition of killing one's self. Thus, killing a person to ease his suffering even though it is at the request of the person will be inconsistent with Islamic law, regardless of the different names given to the procedure, such as, active voluntary euthanasia, assisted suicide or mercy killing. ${ }^{41} \mathrm{~A}$ person in such situation persevere patiently with the available medical treatment as the reward for such patience in the Hereafter is tremendous as promised in Surah al-Zumar, in which Allah S.W.T. states to the effect: "And those who patiently persevere will truly receive a reward without measure." ${ }^{x \times v}$ However, it is not obligatory to administer medical treatment, which is ruled to be definitely useless or futile, particularly if the patient is brain-stem dead $\mathrm{d}^{\mathrm{xxi}}$ and there is no hope of recovery at all. According to a well-known Islamic jurist, Yusuf Qardawi, withdrawal of life support system would be lawful for patients suffering from brain death. ${ }^{42}$ Without these machines, death would be inevitable for these patients and the existence of the machines merely prolong the process of death. Furthermore, since such machines are expensive and scarce, it is not possible to provide them to all patients. Thus, such treatment should be given to those who are able to recover rather than giving to those whose death is inevitable. ${ }^{43}$ In these cases, even though, such medical treatment is withheld, the basic human rights of the patient, which include being provided with food, drink, nursing, and relief from pain must still be provided and this can be done at home. The patient should be allowed to die peacefully and comfortably. ${ }^{44}$

\section{ORGAN TRANSPLANTATION}

Organ transplantation is undoubtedly one of the triumphs of modern medicine. The procedure has become increasingly routine as means of saving and improving the quality of the lives of thousands of people each year. However, transplant activity raises difficult ethical and legal issues in its requirements for donated organs. ${ }^{45}$ Transplantation of cadaveric tissues in Malaysia is governed by the Human Tissues Act 1974. This act allows the removal of tissues from cadavers for therapeutic, medical education and research purposes. Removal of cadaveric tissues is permitted under two circumstances. Firstly, at the express request of the donor. The request may be given at any time in writing or may be stated orally during the deceased's last illness in the presence of two witnesses. ${ }^{46}$ Secondly, in the absence of objection from the deceased and with the consent of the next -of-kin. ${ }^{47}$ The person lawfully in possession of the body is under a duty to take all reasonable steps to find out if the deceased had any objection and to obtain consent from the next-of-kin. ${ }^{48}$ The above act permits the person lawfully in possession of the corpse to authorise the removal and use of parts of the body for any or all of the specified purposes either where the deceased explicitly requested to donate and had not withdrawn this request or, in the absence of such a request, where following such reasonable enquiry as may be practicable there is no reason to believe that either the deceased or any surviving spouse or relative objected to such removal and/or use. ${ }^{49}$ However, the act does not deal with issues relating to the use of parts of bodies of living persons. The Human Tissues Act also does not have specific provisions banning the sale or purchase of organs. In view of the shortcomings of the act, the Ministry of Health is currently drafting a new legislation for organ transplantation that will cover all issues relating to cadaveric and living transplantation as well as commercialization of human organs.

The issue of organ transplant has also been a matter of great debate and dispute amongst contemporary Islamic scholars around the globe. The opinion amongst the majority of Islamic jurists is that seeking medical treatment is either recommended (Mandub) or obligatory (Wajib). There are many Hadiths, which encourage the Muslims to seek medical treatment. ${ }^{\text {xxvii }}$ The prohibition of harvesting organs from the dead for transplant originates from the Hadith which narrated that a man was digging a grave and he stumbled on some bones. The Prophet Muhammad (P.B.U.H). then said: "Breaking the bones of the dead is like breaking the bones of the living." The general rule in Islam is that one should not violate, harm or mutilate the dead body whether Muslim or non-Muslim cadaver, as an act of revenge, showing disrespect or doing so without any good reason. ${ }^{50}$ However, there are exceptions to this general rule especially in the light when there is a necessity (Darurah). Based on Islamic Jurisprudence, the teachings of the Qur'an and Sunnah permit the use of unlawful things in cases of extreme need and necessity. In Surah al-Baqarah, Allah S.W.T. states to the effect that: "Allah S.W.T. has forbidden you dead meat, blood and flesh of the swine and that on which any other name has been invoked besides that of Allah. But if one is forced by necessity, without willful disobedience, or transgressing due limits, then he is guiltless. For Allah is Most Forgiving and Most Merciful."51 The principle of Figh, based on the above Quranic guidelines stated that: "Necessity makes prohibition lawful."xxviii According to Imam Shafii, it is permissible for a person dying out of hunger to consume the meat of another human. ${ }^{\text {xxix }}$ Thus, when a person's life is in danger and he is in need of transplantation, the transplantation whether from cadaveric, live or animal donor would become permissible. Further, a Muslim is allowed to be an organ donor if the intention is to save lives. The human body is given to mankind as a gift but based on trust or amanah that we will use our body in a correct manner. Thus, if organ is donated to save 
another person, then this would be considered as a noble act.

\section{STERILISATION}

Contraception aims at preventing sexual intercourse from resulting in pregnancy. Unlike other contraceptive methods, sterilisation permanently removes the reproductive capacity of a person. Consensual sterilisation by competent adults usually does not present any controversy as long as the couple gives an informed consent to the procedure and this is deemed to be part of their family planning. ${ }^{52}$ Compulsory sterilisation or involuntary sterilisation, on the other hand, presents a host of legal problems due to the conflict between patient autonomy and medical as well as judicial paternalism. On this issue, the Malaysian Medical Law applies the principles of common law, particularly with regards to the criteria on the 'best interests' of the patient. ${ }^{x x x}$

The use of contraceptive method in preventing pregnancy has existed since the Prophet Muhammad's (P.B.U.H). time when he allowed his followers to practice 'azl or coitus interruptus. ${ }^{x x i}$ Modern biomedical sciences have devised many methods of reversible and non-reversible contraceptive methods. Contraceptive methods that will lead to abortion will not be lawful. Reversible contraceptive methods such as using the condom, rhythm method, progestogen pill and injection have been allowed in Islam provided that it is to protect the health of the woman and to allow for proper time to be given in suckling the infant baby. Contraceptive methods can also be used to prevent a couple with hereditary disease to transmit the defective genes to their newborn. Similarly, irreversible methods of sterilisation such as tubal ligation will be permissible, if it is performed only at a limited circumstance where there is a legitimate necessity. ${ }^{53}$ By legitimate necessity, it is meant that no other means is available to protect a woman's life, or that it is confirmed that the child the woman might deliver would be have a serious hereditary disease because the couple are carriers of the disease. ${ }^{54}$ If sterilisation is done for family because the couple is satisfied with the number of children they have, some jurists regard it as permissible but makruh (disapproved act). ${ }^{55}$

\section{CONCLUSION}

It can be seen from the discussion above that there are many similarities between the Malaysian and Islamic law governing issues contemporary issues on negligence, confidentiality, assisted reproductive technologies, abortion, euthanasia, organ transplantation and sterilization. This is due to the fact that legal duties are founded on moral precepts which are inseparable from the teachings of the religion itself. Particularly, Islam as a complete and comprehensive way of life, establishes rights and duties that encompasses all fields of human endeavours whether, spiritual or material. Upholding sanctity of life, respecting rights of patients and autonomy as well as constantly acting in the best interests of the patients have been the core principles advocated in both the Malaysian and Islamic law. This is in conformity with the demands of the five foundational goals of the Maqasid al Shar'iah in the protection of religion, life, lineage, intellect and property. Thus, any deliberations pertaining to contemporary medical issues should flourish within the confines of these goals. Muslim medical professionals should be inculcated with knowledge of legal rulings from both the Malaysian and Islamic perspectives in order for them to be able to execute their duties more holistically and comprehensively. This will eventually promote safer medical practice for the betterment of the society and the ummah.

\section{REFERENCES}

1. The Holy Qur'an $5: 32$.

2. Ibid.

3. Foo Foo Fio $\mathrm{Na} v$ Dr Soo Fook Mun \& Anor [2007] 1 MLJ 593, approved by Zulhasnimar binte Hasan Basri and Another v Dr Kuppu Velumani P and 2 Others, 2017, Civil Appeal No. 02(f)-10-02/2015(W).

4. Liaquat Ali Niazi Khan, Islamic Law of Tort , Lahore : Dayal Singh Trust Library, 1988, at p. 179.

5. Abu Dawud, Kitab ad-Diyat, Cairo: Matba'ah Mustafa, n.d., Vol.18, at p. 108.

6. Imam al-Shafi' $i$, Kitab al-Umm, 6th Ed., Cairo : Matba'ah al-Kubra, $1325 \mathrm{H}$, at p. 175.

7. Al- Nawawi, Muhiudin 'Abu Zakaria Yahya bin Sharif, Minhaj-et-Talibin: A Manual of Muhammadan, Lahore : Law Publishing Company, 1977, at pp. 454 - 455.

8. Ibn Qudamah, Mu' jam al-Fiqh al-anbali, Mustakhla Min Kitab al-Mughni, at p. 804.

9. Al-Khatabi, Ma'alim al-Sunan, Cairo: Matba'ah Ansar al-Sunnah, 1367h, Vol.6, at p. 378.

10. Ibid.

11. Al-Ghamidi, Mas‘uliyyah al-Tabib alMihaniyyah, Jeddah : Dar al- Andalus, 1997, at p. 193.

12. Ibid., at p. 196.

13. Puteri Nemie, J.K. Medical Negligence Law in Malaysia, Kuala Lumpur : International Law Book Services, 2008, at p. 180.

14. Ibid., at p. 197.

15. Ibid.

16. Puteri Nemie, J.K. Medical Negligence Law in Malaysia, Kuala Lumpur : International Law Book Services 2008, at p. 180.

17. Puteri Nemie, J.K. \& Ramli, N. The Inviolability of Medical Confidentiality in Malaysia: An Analysis of its Rules and Exceptions, IIUM Law Journal, 24 (2), 2016, at p. 335.

18. AG v Guardian Newspapers (No 2) [1990] AC 109 at. 282, per Lord Goff.

19. W v Egdell [1990] 1 All ER 835, at pp. 851-852.

20. Sahih Al Tirmidhi, Vol. 28, No. 1977.

www.sunnah.com. Accessed October 25, 2018. 
21. Puteri Nemie, J.K. Law and Ethics Relating to Medical Profession, Kuala Lumpur:

International Law Book Services, 2007, at p. 211.

22. Ibid. at p. 226.

23. The Holy Qur'an, $30: 21$.

24. Sunan Ibn Majah, Vol. 3, Book 9, Hadith 1845. www.sunnah.com. Accessed October 25, 2018.

25. Puteri Nemie, J.K. Law and Ethics Relating to Medical Profession, Kuala Lumpur: International Law Book Services, 2007, at p. 291.

26. The Holy Qur'an, 18:46.

27. Puteri Nemie, J.K. Law and Ethics Relating to Medical Profession, Kuala Lumpur: International Law Book Services, 2007, at p. 291.

28. Omran AR, "Ethical guidelines for human reproduction research in the Muslim world." IICPSR, 1992, pp. 29-31. [Agree - Prof., can we put this as ref? for ref, delete 'See Serour GI et al' Start with: Omran AR (first author?) "Ethical guidelines for human...." ]

29. Aly A Mishal, "Cloning and advances in molecular biotechnology: Islamic Shari'ah guidelines, FIMA Year book 2002, pp. 33-47.

30. Martin, E.A., (Ed.), Oxford Dictionary of Law, New York: Oxford University Press, 1997, at p. 2.

31. The Holy Qur'an, $17: 31$.

32. Sahih Al-Bukhari, Volume 4, Book 55, Number 549, www.sunnah.com.

33. Puteri Nemie, J.K. Law and Ethics Relating to Medical Profession, Kuala Lumpur: International Law Book Services, 2007, at pp. 293-294.

34. McHale, J., Law and Nursing, London: Butterworth-Heinemann, 2007.

35. Puteri Nemie, J.K. Law and Ethics Relating to Medical Profession, Kuala Lumpur: International Law Book Services, 2007, at p. 263.

36. Puteri Nemie, J.K. Law and Ethics Relating to Medical Profession, Kuala Lumpur: International Law Book Services, 2007, at p. 264.

37. Puteri Nemie, J.K. Law and Ethics Relating to Medical Profession, Kuala Lumpur: International Law Book Services, 2007, at p. 272.

38. The Holy Qur'an, 4: 93.

39. The Holy Qur'an, 4:29.

40. Puteri Nemie, J.K. Law and Ethics Relating to Medical Profession, Kuala Lumpur:

International Law Book Services, 2007, at p. 295.

41. The Holy Qur'an, 39:10.

42. Yusuf al-Qardawi, Fatawa Mu'asirah, Dar alWafa il al-Tiba'ah wa al-Nashr wa al-Tawzi, Eqypt, 1993, Vol. 2, pp. 527-529.

43. Ibid.

44. Islamic Medical Ethics by IMANA Ethics Committee, www.imana.org. Accessed October 25, 2018.

45. Puteri Nemie, J.K. Law and Ethics Relating to
Medical Profession, Kuala Lumpur: International Law Book Services, 2007, at p. 227.

46. Ibid., Section 2(1).

47. Ibid., Section 2(2).

48. Ibid., Section 2(1).

49. Puteri Nemie, J.K. Law and Ethics Relating to Medical Profession, Kuala Lumpur:

International Law Book Services, 2007, at p. 296.

50. The Holy Qur'an, $2: 173$.

51. Puteri Nemie, J.K. Law and Ethics Relating to Medical Profession, Kuala Lumpur: International Law Book Services, 2007, at p. 189.

52. Puteri Nemie, J.K. Law and Ethics Relating to Medical Profession, Kuala Lumpur: International Law Book Services, 2007, at p. 299.

53. The Islamic Jurisprudence (Fiqh) Ruling on Surgical Contraception (Sterilization). www. islamset.com. Accessed October 25, 2018.

54. Ibid.

\section{FOOTNOTES}

i. They are presumed to possess all the requirements of taklif (juridical responsibility), as they are adults having the requisite medical knowledge.

ii. It was reported that the Prophet Muhammad (PBUH) said: "Harm is neither inflicted nor tolerated". See Ibn Majah, Sunan Ibn Majah, at http://hadith.al-islam.com/search/

iii. Section 3 of the Malaysian Civil Law Act 1956 states to the effect that Malaysian courts shall apply the common law of England and rules of equity where no provision on the matter has been made by any written law in Malaysia.

iv. [1934] AC 1.

v. This is also known as the Bolam principle, which gives prominence to evidence adduced by the medical profession as to their standard practices. A doctor "is not guilty of negligence if he has acted in accordance with a practice accepted as proper by a responsible body of medical men skilled in that particular art" - per McNair J. in Bolam v Friern Hospital Management Committee [1957] 1 WLR 582, at p. 587.

vi. Ku Jia Shiuen (an infant suing through her mother and next friend, Tay Pei Hoon) \& Anor $\checkmark$ Government of Malaysia \& Ors [2013] 4 MLJ 108, citing Rogers $\vee$ Whitaker (1992) 175 CLR 479.

vii. See the Holy Qur'an, Surah an-Nur, verse 59, "But when children among you come of age, let them (also) ask for permission as do those before them. Thus does Allah make His signs to you, For Allah is full of knowledge and wisdom."

viii. This Charter comprises of ten chapters with 
107 articles. See

http://www.emro.who.int/PDF/islamiccharte r_MedicalHealthEthics.pdf.

ix. Ibid. Article 29.

x. The Islamic Organisation for Medical Sciences (IOMS) first addressed this issue of assisted reproduction in their Figh Medical Seminar in May 1983. This seminar consists of distinguished jurists, Shari'ah experts, medical practitioners, scientists and specialists in other human sciences. The Seminar summarized fundamental ground rules, which must be adhered by Muslim practitioners in the area of ART.

xi. The European Council for Fatwa and Research states that: "It is permissible for the wife to use the sperm of her husband for fertilization unless she is divorced or the husband dies."

xii. The ruling of the Islamic Organisation for Medical Sciences (IOMS).

xiii. [1985] 2 MLJ 122.

xiv. Ibid. at p. 127.

$x v$. Ibid.

xvi. Some minority Malikis allow abortion within the forty days period but beyond this period, it is prohibited.

xvii. Pretty; $X$ and $Y \vee$ The Netherlands; (1985) 8

EHRR 235; R (Pretty) v Director of Public

Prosecutions (Secretary of State For The Home Department Intervening); [2001] UKHL 61; [2002] 1 AC 800; [2001] EWHC Admin 788; Pretty v UK; 2346/02.

xviii. The Malaysian Penal Code (Revised 1997) [Act 574] modeled after the Indian Penal Code provides certain provisions relevant to "causing death intentionally."

xix. Section 299 provides that "whoever causes death by doing an act with the intention of causing death, or with the intention of causing such bodily injury as is likely to cause death, or with the knowledge that he is likely by such act to cause death, commits the offence of culpable homicide." Explanation 1 given under the section stated that "a person who causes bodily injury to another who is labouring under a disorder, disease, or bodily infirmity, and thereby accelerates the death of that other, shall be deemed to have caused his death."

$\mathrm{xx}$. The principle in R $\vee$ Donovan [1934] 2 KB 498 is closely followed, in which it was held that if an act is unlawful in the sense of being in itself a criminal act, it cannot be rendered lawful merely because the person to whose detriment it is done consents to it. No person can license another to commit a crime.

xxi. [1993] 1 All ER 821.

xxii. The Holy Qur'an, 22: 66. Further verse in the Holy Qur'an: "We give life and cause death, and to Us all will return" (Surah Qaaf $50: 43$ ).

xxiii. Quoted by al-Bukhaari.

xxiv. Al-Nisaaii, in his book of the Prophet's traditions, quotes a statement by the Prophet that says, "To kill a believer is more serious, in God's eyes, than the earth coming to an end." Al-Tirmithi quotes the Prophet, pbuh, as saying, "If the dwellers of heaven and the dwellers of earth combined together were responsible for a believer's death, God, the Most Sublime, would place them all, turned upside down, in Hell."

xxv. The Holy Qur'an, 39:10.

$x x v i$. Endorsed by the Third International Conference of Islamic Jurists 1986 in Kuwait.

xxvii. For example, Allah does not create any disease without its respective medicine Bukhaari and Ibn Majah from Abu Hurairah.

xxviii. See Ibn Nujaym, al-Asbah wa al-Naza'ir, at p. 85.

xxix. See Ibn Qudama, al Mughni 9/335.

xxx. F v West Berkshire Health Authority or Re F (Mental Patient: Sterilisation) [1990] 2 AC 1.

xxxi. In a hadith narrated by Jabir "A man came to the Prophet pbuh and said I have a slave girl and we need her as a servant and around the palm groves. I have sex with her and I am afraid she will become pregnant. The Prophet pbuh said, "Practice 'azl with her if you so wish, for she will received what has been predestined for her." 